\title{
RURAL POLICIES FOR SPARSELY POPULATED AREAS IN FINLAND - OLD PROBLEMS, NEW CHALLENGES AND FUTURE OPPORTUNITIES
}

\author{
Toivo Muilu ${ }^{1}$
}

Received 19 November 2020, Revised 3 February 2021, Accepted 17 February 2021

\begin{abstract}
Sparsely populated areas are in many countries seen as regressive regions lacking decent future options and demanding continuous support from the more prosperous parts of the country in question. This paper addresses rural policies drawn up in recent years to govern not only the negative trends but also the opportunities which the thinly populated rural areas of Finland are experiencing. Finland is, in the European context, a very sparsely inhabited country with long distances between population centres. Less populated areas account for $68 \%$ of the land area of Finland but only $5 \%$ of the population. Finland's long tradition of rural policy implementation has resulted in a comprehensive approach also to the policy measures targeting especially the less populated areas.
\end{abstract}

Keywords: sparsely populated areas, rural policy, Finland

Abstrakti: Harvaan asutut alueet nähdään monissa maissa taantuvina alueina, joilla ei ole kunnollisia kehitysnäkymiä ja jotka vaativat jatkuvaa tukea maan vauraammilta alueilta. Tämä artikkeli käsittelee Suomessa toteutettavaa, harvaan asuttuun maaseutuun kohdistuvaa maaseutupolitiikkaa, jonka kohteena ovat kielteisten näkymien ohella myös mahdollisuudet, joiden varaan tulevaisuutta voidaan rakentaa. Suomi on Euroopan kontekstissa hyvin harvaan asuttu maa, jossa on suuret etäisyydet väestökeskusten välillä. Harvaan asuttujen alueiden osuus Suomen maapinta-alasta on 68 prosenttia, mutta vain 5 prosenttia väestöstä. Suomalaisen maaseutupolitiikan pitkät perinteet ovat edesauttaneet laaja-alaisen ja monitoimijaisen lähestymistavan muodostumista myös harvaan asuttua maaseutua koskevassa politiikassa.

Avainsanat: harvaan asutut alueet, maaseutupolitiikka, Suomi

\section{Highlights:}

- Sparsely populated areas are not a burden to the country but rather an asset.

- Their opportunities are central to the transition towards a sustainable society.

- GIS-based regional classification is an effective tool for drawing up policies.

${ }^{1}$ Dr. Toivo Muilu, Natural Resources Institute Finland, Oulu, Finland, e-mail: toivo.muilu@luke.fi, ORCID: 0000-00017592-8506 
- Policy measures in place must be based on a wide partnership between all key actors.

\section{Introduction}

This paper addresses the rural policies drawn up in recent years to govern the negative trends and the opportunities, which the sparsely populated rural areas of Finland are experiencing. The starting point is that Finland is, in the European context, a very thinly inhabited country with long distances between population centres. These areas accounted for $68 \%$ of the land area of Finland but only 5\% of the population in 2018 (Helminen et al., 2020; see also Sireni et al., 2017).

Although the overall economic development of the country was steady until the start of the COVID-19 pandemic in 2020 following a long downturn, 14 of the 20 weakest administrative regions (NUTS3, provinces) out of a total of 66 regions in Nordic countries were located in Finland in 2019, according to Nordregio's Regional Potential Index. The index is based on the demographic, labour market and economic potential of a region. All of the less prosperous areas were rural provinces with a lot of less populated areas (State of the Nordic Region, 2020).

However, the situation of the outlying rural areas is not as hopeless as could be concluded from the analyses based on traditional population and migration statistics. Regardless of the demographic decline and aging population, rural areas are still home to many active people and village communities. New phenomena, such as multiple residency and especially the large number of leisure-time residents spending many months annually in their summer houses (often located in the less populated areas), as much as doubling the population of many rural municipalities seasonally, are also improving the services offered (Lehtonen et al., 2019).

Regional policies in Finland have, for a couple of decades, mostly favoured growth in cities, which is not surprising as it follows a long period of growth in major urban areas. However, this has not meant that the countryside has been forgotten, because Finland has a long-running tradition of implementing rural policies. In recent years, there have been signs of a transition from old and defensive rural policies towards an approach that also identifies the opportunities of rural regions instead of only repeating old problems. Demands on the more sustainable use of natural resources and the resulting new jobs and opportunities connected to the multiple residencies of inhabitants are examples of new phenomena that challenge the prevailing regional and rural policies.

This article seeks to find answers to four main questions: (1) how sparsely populated rural areas are defined and what their context is in the Finnish regional system; (2) how rural policies in Finland are organised; (3) what policies have been drawn up recently to support sparsely populated areas and (4) what results these policies have achieved. The content is divided into four parts. After this introduction, the context of the rural areas in question is presented, introducing how less populated areas are represented in international and national regional classification schemes. The next subchapter addresses the central policy initiatives concerning these areas in Finland. Finally, some concluding remarks are offered.

\section{Theoretical background}

\subsection{Conceptual approaches towards rural areas}

Neither for the city nor for rural areas is there a single, shared by all definition. Roughly speaking, the countryside tends to be defined from three different perspectives. The countryside can be understood as space or territory, or it can be considered as a human-shaped perception (constructivism) of that state or area (Blanc, 1997). Those who define the countryside through the concept of space see the differences in land use between cities and rural areas as essential, resulting in the sparse population and dominance of agriculture being key phenomena in rural areas. When the concept of territory is used, the rural areas are structured not only through a sparse population, but also by long distances between centres. In the mixed space/territory approach, agriculture does not have a central role as a determinant, but the rural areas are seen as a platform for a wide range of livelihoods. According to the constructivist concept, 
the countryside is a mental structure that varies with time and place, as is the city (Blanc, 1997; Terluin, 2001).

Of these concepts, regional and rural policies primarily use either a territorial (such as the Organisation for Economic Co-operation and Development - OECD), or a combination of territorial and spatial approaches (European Union - EU) (Terluin, 2001). The constructivist concept of the countryside is more often used as a tool for researchers attempting to analyse and structure the backgrounds and dynamics of different rural relationships. The EU's rural policy has for long had a strong agrarian tradition, but there have also been varied lines of naturalistic rural relations.

Hoggart et al. (1995) have identified four kinds of approaches in the attitudes of the member countries of the EU towards the countryside. The approaches are of course generalisations, and many attitudes towards rural areas can occur in the same country. However, the concepts help understand the differences of the rural areas in European countries and the varying attitudes to them.

Firstly, there are countries with a strong agrarian tradition in which agriculture determines where the countryside occurs and where agriculture has held an important position in national politics. Examples of these countries are France, Denmark, Ireland, the Netherlands, Belgium and Germany. Secondly, there is the so-called naturalistic countryside tradition in which the countryside has been seen, in the first place, as a landscape and as a nature to be consumed. Rural areas are viewed from the cities, and a strong need for their protection is often connected to this view. This tradition has been strong in Great Britain but also in parts of the Netherlands, Belgium, France, and Germany (Hoggart et al. 1995).

In the Mediterranean area, there has been little ideological or cultural value placed on the countryside. It has commonly been viewed as a declining hinterland between modern cities, which is often difficult to reach in mountainous countries. It has often been considered a burden to the national economy and the country, and people have been driven far away from these areas - either to cities or to foreign countries. This third, Mediterranean countryside perception has been dominant in Spain, Portugal, Italy and Greece.

The fourth countryside category defined by Hoggart et al. (1995) is that of the marginalistic countryside, where rural areas are connected to a physical environment, which is appreciated in culture, but in which conditions are harsh and restricting. Fishing, forestry, agriculture and nature and its protection are connected to the countryside in these countries. This kind of relation to the countryside has prevailed in Sweden, Norway, Finland, Austria, and Switzerland (Hoggart et al., 1995; Vihinen et al., 2019).

In accordance with Hoggart et al. (1995), especially the thinly populated rural areas of Finland can be interpreted as being marginal areas based on their physical properties and locational factors relative to natural conditions. Leimgruber (2004) analyses the concepts of marginality and peripherality and emphasises that these terms must be distinguished from each other. Less populated rural areas in Finland can also be called peripheral inside the country because they are located far from growth centres, and the benefits from the booms and innovations of the economy are commonly delayed (if they arrive at all). When an economic recession occurs, it is the peripheral areas that are the hardest hit and the narrowing of job opportunities for the inhabitants of such areas comes to be reflected in a negative demographic trend (Muilu \& Rusanen, 2003). This is also the starting point for the policies addressed in Chapter 3.

\subsection{Sparsely populated areas in Nordic countries}

Rural areas and regions have for long been defined and classified for the needs of international comparison and statistics, e.g. by the OECD, EU and Nordregio. The United Nations (UN) does not have its own global definition for different regions, although it also publishes statistics and reports from an urban-rural perspective. The United Nations Statistical Division (UNSD) has stated that a uniform and global definition of urban and rural areas is not possible because national definitions are very different. This also makes it difficult to collect international regional statistics and make urban-rural comparisons based on them. The UN therefore notes that each 
country must define its cities and rural areas based on their local circumstances. The UN recommends that the most suitable unit for national and international comparisons is the number of the population of the smallest locality and, if this is not available, that of the smallest regional administrative unit in the country (e. g. municipality). The UN also presents a classification, where the largest category has more than 500,000 inhabitants and the smallest less than 200 (Dijkstra \& Poelman, 2014; UNSD: Population density and urbanization, 2017).

The most recent international regional classification including Finland is the urban-rural classification produced for the Nordic Council of Ministers by Nordregio. It is provincial (NUTS 3) and based on the Eurostat statistics (Nordic Council of Ministers, 2018). Based on its sparse population, long distances between population centres and relatively small number of big urban areas, Finland, like the other Nordic countries, is an exceptionally rural country compared with a large number of other developed countries. Finland is also marked by a considerably large proportion of rural land areas from the total area. Another exceptional feature in Finland compared with many other thinly populated countries is that almost the entire country is still inhabited, even if thinly (Nordic Council of Ministers, 2018).

The northernmost provinces of Finland, Norway and Sweden have established the Northern Sparsely Populated Areas (NSPA) collaborative network in 2004 to raise awareness of the common issues and circumstances facing these regions within EU institutions, to influence EU policy and to provide a platform for delivering the best policy practices. The NSPA includes the four northernmost provinces of Sweden (Norrbotten, Västerbotten, Jämtland-Härjedalen, and Västernorrland), the seven northernmost and eastern regions of Finland (Lapland, Northern Ostrobothnia, Central Ostrobothnia, Kainuu, North Karelia, North-Savo and South-Savo) and three regions of northern Norway (Finnmark, Troms and Nordland) (Figure 1) (NSPA 2019).

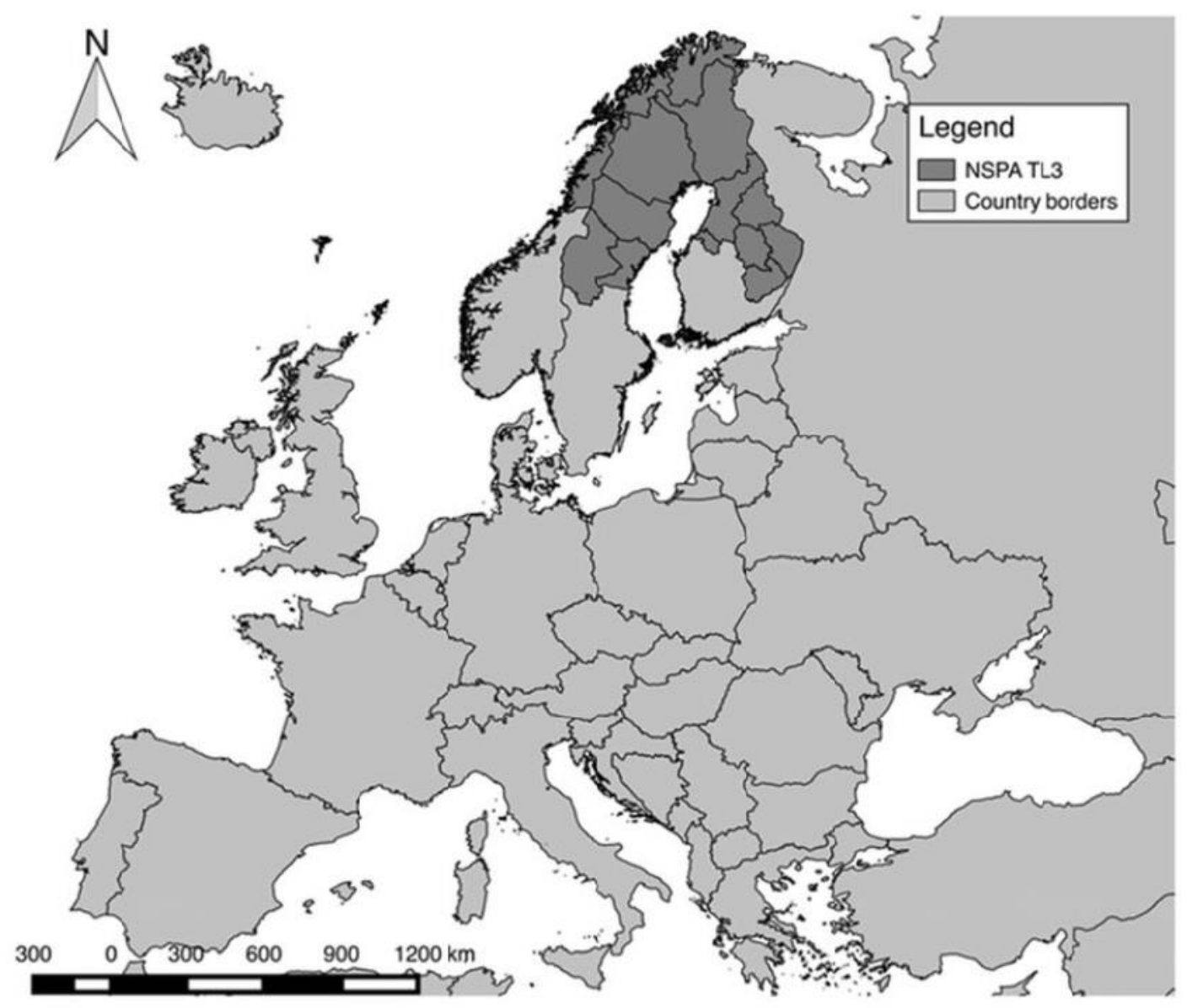

Note: Territorial level 3 (TL3) consists of micro regions within each OECD country. Each member country has identified the statistical or administrative geography that provides the best fit for this territorial classification.

Fig 1. Northern Sparsely Populated Areas (NSPA) in Finland, Norway and Sweden. Source: OECD, 2017 


\subsection{Sparsely populated areas in Finland}

In Finland, several regional classifications which describe and define rural areas and rurality have been used. They have also been utilised in the regionalisation of national agricultural and rural policies, as in the targeting of support measures or setting certain support levels. The developments and characteristics of different types of rural areas have also been described with the help of these classifications (Vihinen et al., 2019).

Muilu and Rusanen (2004) emphasise that the countryside is not an entity in itself but a mosaic composed of highly disparate parts. It can, and should, be defined in accordance with the purpose for which the definition is needed. Georeferenced (GIS) data can be used to seek answers for a wide variety of questions concerning the internal structure of rural areas, simply by extending the range of variables.

A GIS-based urban-rural classification is the newest widely used rural and regional classification scheme in Finland. The classification was published in 2014 and is based mainly on data from 250-square-meter grid cells. The areas have been divided into seven classes, from inner urban areas to sparsely populated rural areas (Helminen et al., 2014). The classification has been updated in 2020 so that it is based on the 2018 statistical data (Helminen et al., 2020; Urban-rural classification, 2018). The classes and their location are shown in Figure 2.

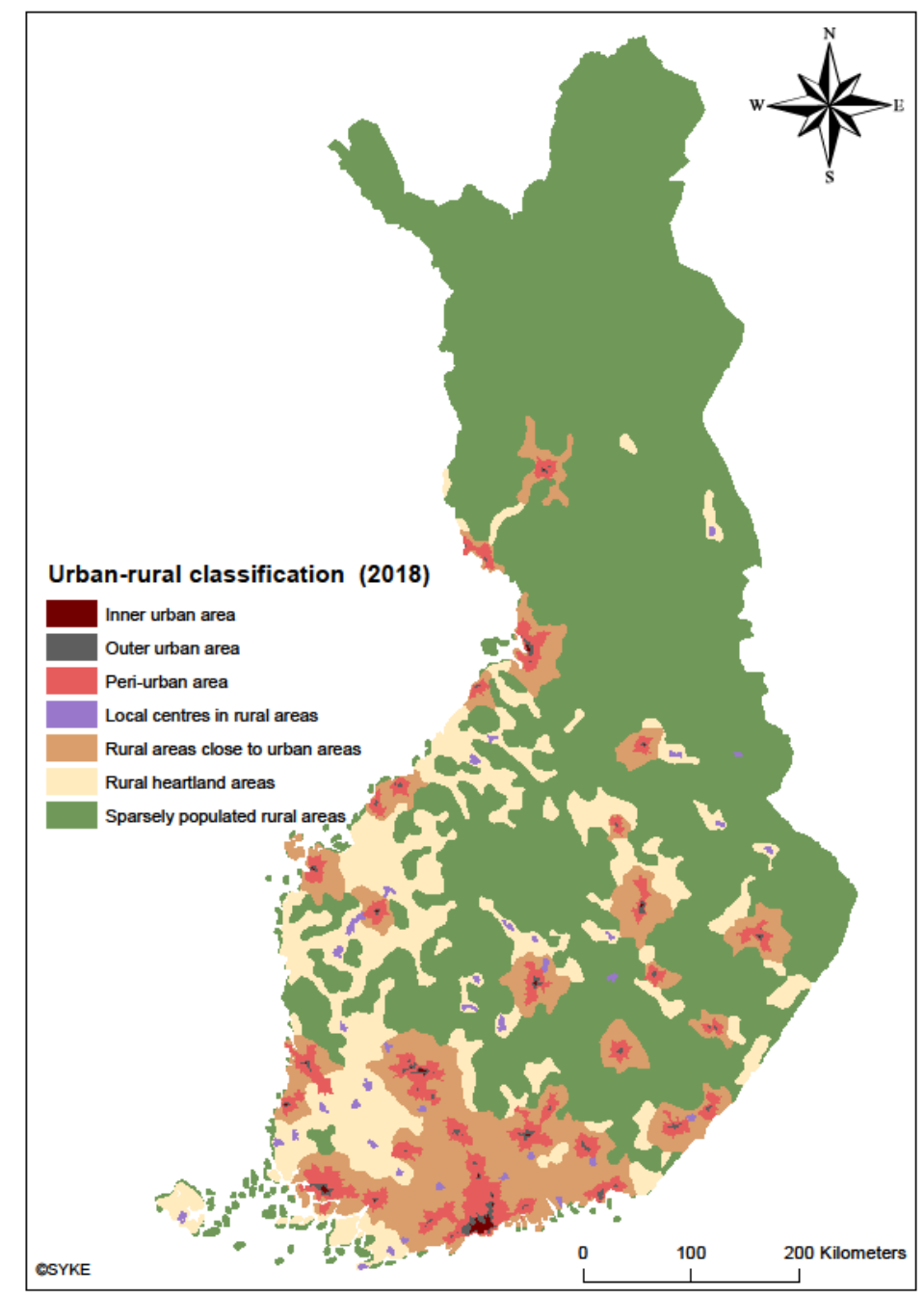

Fig 2. Urban-rural classification (Kaupunki-maaseutuluokitus) of Finland in 2018. Sources: Helminen et al., 2014; 2020; Urban-rural classification, 2018

This classification responded to the need to create regionally more accurate classifications independent from using administrative borders, like those between the municipalities, since the municipality structure is changing over time due to the municipality mergers and the average 
size of the municipalities is thus increasing. The base material for the classification has included databases on population, workforce, commuting, construction, road networks and land use. The GIS-based classification can also be generalised to the municipal level so that the municipalities are divided into urban, peri-urban, rural heartland and thinly populated municipalities, according to the dominant class (Helminen et al., 2014).

In the classification, sparsely populated rural areas are defined based on statistical analysis as areas characterised by a one-sided local economic structure, sparse population and forests or bogs as the most common land use category. These areas are located far from the big population centres. However, it is essential to note that not only is the general population structure there sparse, but the local administrative centres and villages are also scattered and there may be large uninhabited areas between them. Thus, less populated rural areas are those rural areas that do not meet the criteria of local centres in rural areas, rural areas close to urban areas, or rural heartland areas (Helminen et al., 2014).

Between 2014 and 2018, the core rural area decreased the most in terms of area, as it lost areas to both the rural areas close to the urban areas and to thinly populated rural areas. Both periurban rural areas and local centres in rural areas have maintained their population shares, but the population shares of the heartland and less populated rural areas have declined. As a whole, the area of sparsely populated rural areas has decreased because, in addition to the core rural areas, it has moved to rural areas close to urban areas (Helminen et al., 2020; Urban-rural classification, 2018).

\section{Policies and planning initiatives for sparsely populated areas}

\subsection{System of rural policy in Finland}

Rural policy has a long tradition in Finland, celebrating its 30 -year journey in 2018. The objectives, tools and measures of rural policy are collated in Rural Policy Programmes, the first of which was drawn up in 1991. The latest Rural Policy Programme was drawn up for the years 2014-2020, and so it follows the programme development period of the regional and rural development of the EU (Mahdollisuuksien maaseutu, 2014; Maaseutuja tulevaisuudessa, 2018). In 2020, the next programme for 2021-2027 was under preparation.

Finnish rural policy is based on a wide partnership where the actors of the public, private and third sector (NGOs) look for common objectives and measures around the same "round table". OECD reviewed Finland's rural policy in 2008 and stated that Finland is one of the most rural of the OECD countries, and it is also one of the early adopters of a multi-sectoral approach to rural policy. The Finnish model of rural policy has been reasonably successful in achieving coherence among sectoral policies oriented to rural areas (the so-called broad rural policy) and in tailoring specific programmes to promote rural development (the so-called narrow rural policy) (OECD, 2008).

There have been different stages in the development and execution of the rural policy but it has always been led by a cooperative body, which is subordinate to a ministry. At present, the rural policy is coordinated by the Rural Policy Council of Finland under the Ministry of Agriculture, set by the Government of Finland. The council has a high political profile, since the chairman of the council is the Minister of Agriculture and Forestry, and the Minister of Economic Affairs acts as its vice-chairman. In assembling the council, attention has been paid to the cross-sectoral character of the rural policy, which crosses the spheres of responsibilities of different ministries. There are 35 individual members in the council, representing actors from all three sectors of society and from local to national levels (Maaseutupolitiikan neuvosto, 2019).

The main task of the Rural Policy Council is to support the government in administrative and strategically important rural policy issues. It leads and outlines the implementation of the rural policy of Finland. Ten sub-tasks have also been pursued by the council, including the development of the structures and implementational mechanisms of rural policy, with the help of the network-like partnership; promoting place-specific policy; improving interactions between rural, archipelago and urban areas in cooperation with the drivers of urban and archipelago 
policies; and consolidating rural research and know-how from national rural research and development projects (Maaseutupolitiikan neuvosto, 2019).

The networks of the Rural Policy Council are central implementers of the tasks of the council. The networks are responsible for developing rural policy and preparing policy measures in their own areas of interest, according to the outlines set up by the council. Five thematic networks were in action in 2020 and one of them is the Network for Sparsely Populated Areas (in Finnish: Harvaan asutun maaseudun verkosto). There is a total of 19 individual members in the Network, representing the Members of Parliament, researchers and the representatives of ministries and regional development authorities, for example, (Maaseutupolitiikan neuvosto, 2019).

\subsection{Strategy for Sparsely Populated Rural Areas 2017-2020}

The most important policy programme concerning thinly populated areas in recent years in Finland has been the Strategy for Sparsely Populated Rural Areas 2017-2020, which was prepared by the Network for Sparsely Populated Areas in 2017. Two tasks were set for the strategy: "Firstly, the strategy for sparsely populated rural areas aims to create a realistic picture of the status, future and special conditions of thinly populated rural areas. Secondly, it strives to describe the measures by which the potential of these areas can be fully used." (Lukkari, 2017).

The Strategy differs from many earlier rural policy documents and plans in Finland in that the starting point for it is not to describe the poor development and declining population of the thinly populated rural areas. On the contrary, the Strategy is based on the considerable resources of the areas and on describing their developmental potential. The less populated areas are considered in the strategy as a national asset because this is where the majority of the material and immaterial resources of Finland are located; this is central to the future of the bioeconomy and for achieving a sustainable society. This is also seen in the vision of the Strategy (Lukkari, 2017):

Vision: In the sparsely populated rural areas of Finland, there are plenty of natural resources, the utilising of which increases the possibilities of the area, among others, through the growing bioeconomy. The landscape that has been well taken care of increases the satisfaction and the pulling force of the area as a residential environment. Housing and living in the sparsely populated rural areas are versatile. The inhabitants participate in the developing of their community actively. Within reach of everybody, there are quick and reasonable data networks. The new ways of producing services make welfare, housing, business and fluent everyday life possible.

In the background section of the Strategy, five central and interconnected development trends which will affect the development of the thinly populated countryside of Finland in the near future are described. First, the significance of the leisure-time inhabitants (like summer cottagegoers) increases from the point of view of the vitality of the less populated areas when the size of the resident population decreases. This increases multiple residencies, a phenomenon where people spend even months annually in their second homes, doing telework and mixing leisure and working time (Lehtonen et al., 2019). In Finland, there are about 500,000 summer cottages which is quite a lot compared to the number of inhabitants in the country (5.5 mil. inh.). The number of summer residents has multiplied over the last few decades (Adamiak et al., 2016). It has been estimated that about 2.2 million of the total of 5.5 million Finns regularly spend time in rural areas (Mökkibarometri $=$ Summer Cottage Barometer, 2016). Despite the increasing significance of the summer cottage-goers, tourists, and other part-time residents in the rural areas, they are not considered potential customers for public and private services (Lehtonen et al., 2019).

The new tools required for the production of services in less populated and remote rural areas are the second development trend that is described in the Strategy. The declining population does not provide a sufficient base for permanent public services, such as social and health services in outlying and less populated municipalities. In small rural municipalities in northern and eastern Finland, health and social security expenditures can make up as much as $70 \%$ of the expenses 
of municipalities while the comparable share in southern Finland is about $40 \%$. As a solution, among others, decentralised service models have been presented (Lukkari, 2017). Lehtonen et al. (2019) have made calculations according to which the multi-service centres could provide a cost-efficient service model, especially if attention is paid to the seasonal inhabitants' needs for services in the placing of the centres.

The third trend touching especially thinly populated rural areas consists of the changes in the ways regional and local administration and the production of the public services are arranged. The base of the Finnish welfare state has been eroded by structural changes in the economy and working life, which have impacted on regional development and deepened differences, such as the level of vitality, between the areas. Strengthening the role of markets and the third sector has been attempted to bolster the thinning of the public service network. Relations and tasks between municipalities and the regional government (provinces) are being reorganised and the role of the municipality is expected to change in the future. Especially in the less populated rural municipalities, there has for long been a hybridisation process in the ways of the arrangements of service actions that have been traditionally assigned either to the private or the public sectors. In these discussions, a more significant role than before in carrying out services and patching service holes has been reserved for the village associations and other third sector organisations. New ways of producing services will become common, and the same time, new forms of employment will be needed. Partnerships between the public, private and the third sectors may bring new possibilities of development to the less populated areas (Pihlaja, 2010; Lukkari, 2017).

The fourth trend shows a change in the forms of entrepreneurship and of livelihood. Changes in working life are happening fast (as seen also during the COVID-19 pandemic), and the number of regular jobs has diminished, since an increasing number of people are getting their livelihood from many sources. New jobs are being created mainly in small and medium-sized companies, which is typical also in the thinly populated countryside. As many as $99.8 \%$ of Finnish companies are small and medium-sized - in other words, companies with fewer than 250 employees. More than $93 \%$ of the enterprises are micro-enterprises with fewer than 10 employees (Entrepreneurship statistics, 2017). Eighty percent of the industrial enterprises are located outside the Helsinki metropolitan area. This is due to the location of raw materials in rural regions, logistical reasons, and thus cost efficiency. Business activity is promoted by a safe and steady environment, functional traffic connections, telecommunication networks and reliable support services. In the less populated areas, there have traditionally been multiple sources of livelihood. The jobs of the future will use new technologies, such as robotics and digitalisation. The multiskilled employees of the countryside therefore hold a strong position in the future labour market (Lukkari, 2017).

As a fifth trend, the Strategy highlights the meaning and development of infrastructure, which consists of fast and reliable telecommunications, an operational road network, reliable electricity, water supply and sewerage, improved means of transport (air traffic, railroads, bus and taxi traffic, connection vessels, private motoring), land use issues and problems related to the abandonment of real estate in rural areas. Having these infrastructures in place enables the operation of companies, the development of the bioeconomy and the movement and operation of permanent, seasonal, and multi-resident inhabitants. All these activities and phenomena are common in thinly populated areas. The countryside can test and bring into operation new services and techniques made possible by developments in technological infrastructure and digitalisation in different sectors. Indeed, the quick broadband connections with fiber-optic cables are necessary living requirements in less populated rural areas (Pyykönen \& Lehtonen, 2016; Lukkari, 2017).

How is the Strategy for Sparsely Populated Rural Areas for 2017-2020 purposed to react to these trends? Only the most important and central measures from the point of view of thinly populated rural areas have been selected for the Strategy. Development targets and measures are divided into five different themes:

- Measures that are cross-cutting and important for the whole Strategy;

- Measures concerning renewing, innovative and networked entrepreneurship;

- Measures concerning the sustainable utilisation of nature and the supply of raw materials; 
- Measures concerning public services, and

- Measures addressing infrastructure and land use

The Strategy has a total of 21 measures, some of which are more general and some which are detailed. They are grouped under these five themes presented in Table 1. The table also provides some examples of measures for each theme. The major idea behind these measures is that the responsibility of implementing each of them is given to a certain quarter or a group of quarters, like the ministries or regional development organisations. So, the measures are not meant to be just political declarations, but effective rural policy acts.

Tab 1. Key themes and examples of the policy measures of the Strategy for Sparsely Populated Rural Areas 20172020. Source: Lukkari, 2017

\begin{tabular}{|l|l|}
\hline Theme & (N, number in programme), examples of the measures \\
\hline Cross-cutting measures & $\begin{array}{l}\text { (2) Improved attention to the problems of sparsely populated rural } \\
\text { areas by taking the rural proofing (evaluation) method into use. } \\
\text { Development of the present indicators to better take into account the } \\
\text { conditions of sparsely populated areas in decision-making. }\end{array}$ \\
\hline $\begin{array}{l}\text { Renewing, innovative and } \\
\text { networked } \\
\text { entrepreneurship }\end{array}$ & $\begin{array}{l}\text { (8) The municipalities and provinces add into their acquisitions of local } \\
\text { services and products. In acquisition, qualitative criteria are brought } \\
\text { into use in the form of environment and social aspects. Acquisitions } \\
\text { are split into smaller parts. }\end{array}$ \\
\hline $\begin{array}{l}\text { Nature and the supply of } \\
\text { raw materials are utilised } \\
\text { in a sustainable manner }\end{array}$ & $\begin{array}{l}\text { (12) Development of nature-based health and welfare services by } \\
\text { increasing customers' freedom of choice and awareness on the } \\
\text { service production by utilising the quality criteria of acquisitions and } \\
\text { experiments. }\end{array}$ \\
\hline $\begin{array}{l}\text { Public services are } \\
\text { obtained through new } \\
\text { forms of services and } \\
\text { partnership }\end{array}$ & $\begin{array}{l}\text { (15) Development of service solutions and experiments in sparsely } \\
\text { populated rural areas in order to promote decentralised service } \\
\text { models (e.g. decontrol of regulations, SGEI (Services of General } \\
\text { Economic Interest), PPP (Public-Private-Partnership), multi-service } \\
\text { centres, social enterprises, mobile services). }\end{array}$ \\
\hline $\begin{array}{l}\text { Infrastructure makes living } \\
\text { and business operations } \\
\text { possible }\end{array}$ & $\begin{array}{l}\text { (18) Fast and reasonably priced broadband } \\
\text { is part of the basic infrastructure. The minimum speed of universal } \\
\text { service communications in dwellings and second homes will be raised } \\
\text { to 100 Mb or more. } \\
\text { (21) Promotion of rural construction by facilitating planning and } \\
\text { building licensing in the legislation. }\end{array}$ \\
\hline
\end{tabular}

The five thematic networks of the Rural Policy Council are responsible for carrying out the Strategy practically. In 2020, besides the Network for Sparsely Populated Areas at hand, the following thematic networks were also active: Vital Operational Environment, Civic Activity and Welfare, Know-How and Employment and Swedish-Speaking Areas (Maaseutupolitiikan neuvosto, 2019). At the time of the writing of this paper, the evaluation of the Strategy was in progress. The Network for Sparsely Populated Areas has been quite active in promoting the Strategy, e.g., by giving public statements which apply to the measures in a political preparation process. The Strategy also has parliamentary support (see Chapter 3.3), and some of its measures have been directly taken to the programmes of the present Government of Finland (Harvaan asuttu maaseutu, 2019).

\subsection{Parliamentary Working Group on Sparsely Populated Regions 2017-2019}

The Government set up the first Parliamentary Working Group on the Sparsely Populated Regions in the autumn of 2017, in connection with the Strategy described above. A Member of Parliament from the biggest parliamentary party in the Finnish Parliament acted as the chairman of the Group and the chair of the Network for Sparsely Populated Areas acted as its vicechairman. Other members of the Group were invited from the other parliament parties. In 
the Group, there were altogether two Members of Parliament from the four biggest parties represented in the Parliament and one representative from other (including the opposition) parties of the Parliament. Permanent experts from the Ministry of Finance, the Ministry of Employment and the Economy and the Ministry of Agriculture and Forestry were also appointed to the Group. The secretary general of the Rural Policy Council and the special expert of the Network for Sparsely Populated Areas acted as the secretaries to the Group (Harvaan asuttujen alueiden parlamentaarinen työryhmä, 2019). A new group working until June of 2023 was appointed in October of 2020.

The main task of the first Parliamentary Group was to bring the measures proposed in the Strategy for Sparsely Populated Rural Areas 2017-2020 into legislative and administrative policy and into practice. The Group studied the measures and their impacts theme-specifically and through intermediate reports, drew up concrete presentations semi-annually during its term in office. The Group has presented statements on tax relief applicable to thinly populated areas and on possibilities connected to regional support, among others. Furthermore, it has explored promoting the use of the rural proofing (evaluation) method as an obligatory procedure in less populated areas. The Group also seeks close communication with actors in thinly populated areas in Finland and with comparable rural policy bodies in other Nordic countries (Työryhmän linjaukset, 2019).

The Parliamentary Working Group on the Sparsely Populated Regions is a political lobbying body for which there is strong political support (see Woods, 2011, for an example of stages in the political construction of the "rural" in England). The work of the Group is somewhat invisible in the sense that it has no exact action plan to be followed. However, as far as is known, it is the first parliamentary organ ever in Finland whose task is solely to promote the matters of thinly populated rural areas.

The new Government of Finland was appointed in the spring of 2019 and the Group lobbied them to pay attention in the government programme to the sparsely populated countryside areas. The Group has also succeeded in some of its objectives, since it has been estimated that nearly $70 \%$ of the objectives and measures of the Strategy were raised in some form in the present government programme. The evaluation report on the activities of the Group operating in 20172019 , states that the monitoring of the measures taken is not recorded in the group's letter of appointment. Many of the group's proposals for action are broad principles that require specific measures and funding opportunities. The evaluation report emphasises the need for practical experiments and pilots to start in thinly populated areas, which relate to the implementation of these measures (Lukkari \& Åström, 2019).

\section{Concluding remarks and discussion}

The context and situation of less populated rural areas in Finland and key recent policy measures targeting these areas especially have been presented in this article. The areas in question can be defined as belonging to the marginalistic countryside, which is also peripheral inside the country (Hoggart et al. 1995; Leimgruber 2004). They have often been considered a burden to the national economy and to regional development because they have long ago lost their population to southern Finland and to the biggest cities. However, the situation is not black and white, since thinly populated rural areas contain many possibilities which have been brought to light in the political sphere during the past few years.

Four main tasks were set for the article: (1) how sparsely populated rural areas are defined and what their context is in the Finnish regional system; (2) how the rural policy in Finland is organised; (3) what policies have been implemented recently to support sparsely populated areas and (4) what results these policies have achieved so far. Four answers and conclusions can be drawn from the analysis.

Firstly, the present seven-level regional classification of Finland offers a good base on which to undertake reliable regional comparisons and target policy actions precisely in regions in question. The classification covers all parts of the regional structure, from the inner urban areas to sparsely populated areas, and so it builds a continuum between different areas, and thereby, separate rural classifications are no longer needed. Thanks to being GIS-based techniques, 
the classification is independent of administrative divisions and operates irrespective of changes in them.

Secondly, rural policy has been developed for more than 30 years in Finland and it has been recognised as progressive in the international context. Rural policy is based on a wide partnership where both the representatives of the sector administration and the actors of the horizontal local administration are collected around "round tables." This has created many personal connections exceeding the branch and lobbying limits and is therefore extremely important to crossadministrative activities, like rural policy.

Thirdly, the two policy initiatives presented in this article have brought the less populated rural areas into consideration on to the national political agenda. The nomination, especially of the Parliamentary Working Group on the Sparsely Populated Regions, points to a genuine and wide political interest in the matter, because the body operates directly in connection with Parliament and is at the core of political preparation processes. As far as is known, the Group is the first parliamentary organ including all parties which concentrates particularly on issues facing thinly populated rural areas.

Finally, the most important question is naturally the effectiveness of the policy initiatives presented above. Has the situation of less populated rural areas of Finland improved and does the future look bright? Any unambiguous answer cannot be given since the planning and political processes are slow and the two described policy initiatives have operated only for a few years. However, according to the Rural Barometer (Maaseutubarometri, 2020), maintaining the vitality of the Finnish countryside has widely received citizens' support, and the measures of the Strategy for Sparsely Populated Rural Areas 2017-2020 are clearly more visible than ever before in governmental policies. The sparsely populated areas in question and their resources are no longer seen merely as a burden but more as an asset.

\section{Acknowledgements}

This work was supported by the ROBUST (Rural-Urban Outlooks: Unlocking Synergies) project, funded by the European Union's Horizon 2020 Research and Innovation Programme (grant agreement No 727988).

\section{Academic references}

[1] Adamiak, C., Pitkänen, K. \& Lehtonen, O. (2016). Seasonal residence and counterurbanization: the role of second homes in population redistribution in Finland. GeoJournal 82(5), 1035-1050. DOI: 10.1007/s10708-016-9727-x.

[2] Blanc, M. (1997). Rurality: Concepts and approaches. [Unpublished paper presented at the 48th Seminar 'RuralRestructuring within Developed Economies' of the European Association of Agricultural Economists, Dijon, March 20-21, 1997].

[3] Dijkstra, L. \& Poelman, H. (2014). A harmonized definition of cities and rural areas: the new degree of urbanisation. [Working Papers 01/2014]. Brussel: EC Directorate-General for Regional and Urban Policy.

[4] Helminen, V., Nurmio, K., Rehunen, A., Ristimäki, M., Oinonen, K., Tiitu, M., Kotavaara, O., Antikainen, H. \& Rusanen, J. (2014). Kaupunki-maaseutu -alueluokitus. Paikkatietoihin perustuvan alueluokituksen muodostamisperiaatteet. Helsinki: Suomen ympäristökeskus.

[5] Helminen, V., Nurmio, K., Vesanen, S. (2020). Kaupunki-maaseutu-alueluokitus 2018. Helsinki: Suomen ympäristökeskus.

[6] Hoggart, K., Buller, H. \& Black, R. (1995). Rural Europe: Identity and change. London: Arnold.

[7] Lehtonen, O., Muilu, T. \& Vihinen, H. (2019). Multi-local living - an opportunity for rural health services? European Countryside 11:2, 257-280. DOI: 10.2478/euco-2019-0013. 
[8] Leimgruber, W. (2004). Between global and local: marginality and marginal regions in the context of globalization and deregulation. Aldershot: Ashgate.

[9] Lukkari, T., ed. (2017). Harvaan asuttu maaseutu - mahdollisuuksia täynnä. Harvaan asutun maaseudun strategia 2017-2020. Helsinki: Ministry of Agriculture and Forestry.

[10] Lukkari, T. \& Åström, C., eds. (2019). Harvaan asuttujen alueiden parlamentaarisen työryhmän loppuraportti. Helsinki: Ministry of Agricultre and Forestry.

[11] Muilu, T. \& Rusanen, J. (2003). Rural young people in regional development - the case of Finland in 1970-2000. Journal of Rural Studies 19(3), 295-307. DOI: 10.1016/S07430167(03)00003-2.

[12] Muilu, T. \& Rusanen, J. (2004). Rural definitions and short-term dynamics in rural areas of Finland in 1989-97. Environment and Planning A 36, 1499-1516. DOI: 10.1068/a36169.

[13] Pihlaja, R. (2010). Kolmas sektori maaseutukunnissa. Helsinki: Helsingin yliopisto, Ruraliainstituutti.

[14] Pyykönen, M. \& Lehtonen, O. (2016). Tietoliikenneyhteyksien merkitys maatilojen ja kuntien kehityksessä. Helsinki: Luonnonvarakeskus.

[15] Sireni, M., Halonen, M., Hannonen, O., Hirvonen, T., Jolkkonen, A., Kahila, P., Kattilakoski, M., Kuhmonen, H-M., Kurvinen, A., Lemponen, V., Rautiainen, S., Saukkonen, P. \& Åström, C. (2017). Maaseutukatsaus 2017. Helsinki: Ministry of Agriculture and Forestry.

[16] Terluin, I. (2001). Rural regions in the EU: exploring differences in economic development. University of Groningen.

[17] Vihinen, H., Voutilainen, O. \& Muilu, T., eds. (2019). Manner-Suomen maaseudun kehittämisohjelmien aluetalous- ja työllisyysvaikutukset - vaikuttavuusarviointi kaudelta 2007-2013. Helsinki: Ministry of Agriculture and Forestry.

[18] Woods, M. (2011). Rural. Routledge.

Other sources

[19] Finnish Environment Institute SYKE (2014). Urban-rural spatial classification of Finland 2014. file:///C:/Users/ppo64/Downloads/UrbanRuralClassification\%20(1).pdf.

[20] Entrepreneurship statistics $2017 \quad$ (2017). Suomen $\quad$ Yrittäjät https://www.yrittajat.fi/sites/default/files/yrittajyystilastot2019_en.pdf.

[21] Harvaan asuttu maaseutu (2019).

https://www.maaseutupolitiikka.fi/paatoksenteon_tueksi/maaseutupoliittiset_verkostot/harva an_asuttu_maaseutu_\%28hama\%29.

[22] Harvaan asuttujen alueiden parlamentaarinen työryhmä (2019). https://mmm.fi/harvaanasuttujen-alueiden-parlamentaarinen-tyoryhma.

[23] Maaseutubarometri 2020: Maaseutu on hyvän elämän paikka 61 prosentille suomalaisista. https://www.maaseutupolitiikka.fi/uutiset/maaseutu-on-hyvan-elaman-paikka-61-prosentillesuomalaisista.

[24] Maaseutuja tulevaisuudessa (2018). Maaseutupolitiikan 30-vuotisjuhlanumero. Maaseudun uusi aika 26:2-3. http://www.mua-lehti.fi/mua-2-3-2018-maaseutuja-tulevaisuudessa/.

[25] Maaseutupolitiikan neuvosto (2019). Rural Policy in Finland. https://www.ruralpolicy.fi/.

[26] Mahdollisuuksien maaseutu (2014). Maaseutupoliittinen kokonaisohjelma 2014-2020. Työja elinkeinoministeriön julkaisuja, Alueiden kehittäminen 9/2014. https://www.maaseutupolitiikka.fi/files/4540/Mahdollisuuksien_maaseutu_25022014.pdf. 
[27] Mökkibarometri (2016). FCG Finnish Consulting Group Oy. Helsinki: Maa- ja metsätalousministeriö, Saaristoasiain neuvottelukunta. http://mmm.fi/documents/1410837/1880296/Mokkibarometri+2016/7b69ab48-5859-4b558dc2-5514cdfa6000.

[28] Nordic Council of Ministers (2018). State of the Nordic Region 2018. http://norden.divaportal.org/smash/get/diva2:1180241/FULLTEXT01.pdf.

[29] Nordic Council of Ministers (2020). State of the Nordic Region 2020. Nord 2020:001 https://pub.norden.org/nord2020-001/\#18421.

[30] NSPA (2019). Northern Sparsely Populated Areas. http://www.nspa-network.eu/.

[31] OECD (2008). OECD Rural Policy Reviews: Finland 2008. OECD Rural Policy Reviews. OECD Publishing, Paris. DOI: https://dx.doi.org/10.1787/9789264041950-en.

[32] OECD (2017). OECD Territorial Reviews: Northern Sparsely Populated Areas. OECD Territorial
DOl: https://dx.doi.org/10.1787/9789264268234-en

[33] Työryhmän linjaukset (2019). Harvaan asuttujen alueiden parlamentaarinen työryhmä https://mmm.fi/documents/1410837/2434364/Harvaan+asuttujen+alueiden+parlamentaaris en+ty\%C3\%B6ryhm\%C3\%A4n+linjaukset+27022019+otsikoittain+ryhmitelty.pdf/a6cb193b9730-5099-eb31-

3d2e63e9659f/Harvaan+asuttujen+alueiden+parlamentaarisen+ty\%C3\%B6ryhm\%C3\%A4 n+linjaukset+27022019+otsikoittain+ryhmitelty.pdf.pdf.

[34] UNSD: Population density and urbanization (2017). https://unstats.un.org/unsd/demographic/sconcerns/densurb/densurbmethods.htm.

[35] Urban-rural classification 2018 (2020). https://www.ymparisto.fi/enUS/Living_environment_and_planning/Community_structure/Information_about_the_comm unity_structure/Urbanrural_classification. 